\title{
第57回日本内科学会講演会 (1960年)
}

\section{シンポジウム（日本循環器学会と合同） \\ 心電应の臨床 \\ V. 刺激伝導障害}

\section{三重県立大学医学部教授}

高安正夫

刺激伝導障害には洞房ブロック，房室ブロック 等結節に於ける障害と心房及び心室内での障害と が考えられる.本シンポジウムでは限られた時間 でもあり前者を割愛して專ら心房内及び心室内伝 導障害を取りあげることとした。

\section{第 1 章 心房内刺激伝導障害}

生理学の教えるところでは心房内に於ける特種 心筋は洞結節と田原結節のみで, 洞結節より発し た刺激が㳽慢性に放射状に抎がりその一部が田原 結節にも到達して興奮を来たすということになつ ている，併し他方 Condorelli1) は両結節間及び 両房に対しても特種伝導系路が存在することを主 張し, 又その後 Schrumpf ${ }^{2}$, Laufer ${ }^{3)}$, Decherd ${ }^{4}$, 前川及び高安 5), 緒方6) 等の特種心筋系 路の存在を肯定せねば説明困難な臨床報告がなさ れている．演者はこの存在を信じて長年にわたり 実験的にその証明につとめて来たが，心室に於け るヒス束，両脚，プルキンエ線維に及ぶ如き強力 な特種心筋は認められないけれども，一応洞結節 より田原結節に至る数条の経路及び左房に至る特
図 1 . 心房内刺激伝導障害の諸型 a.

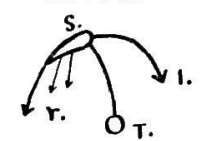

b. Sino-left atrium

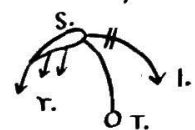<smiles>CCCCC</smiles>

c.

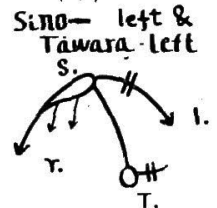

d. Sino-Tawara

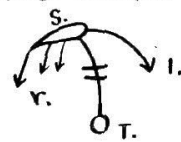<smiles>CCCCC</smiles>

e. Sino-right atrium

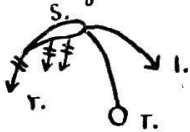<smiles>CCC(C)(C)NC</smiles>

$f \cdot$ sino-right\& left

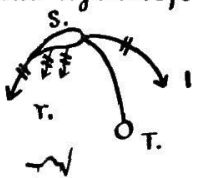

\section{Site of Disturbance}

図 2.洞，左房刺激伝導障害の症例

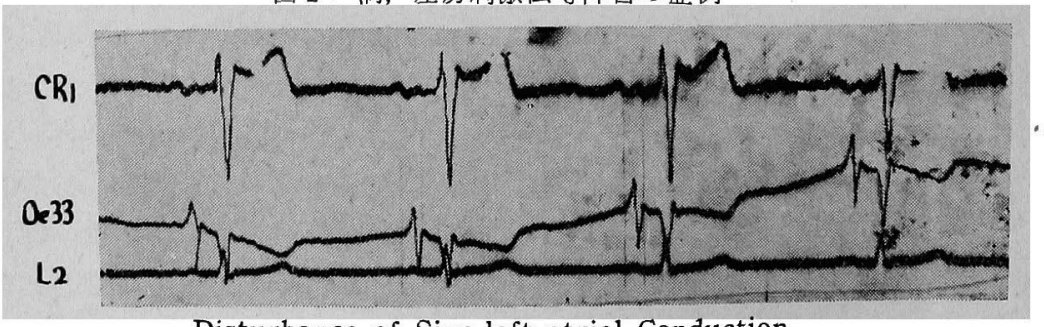

Disturbance of Sino-left atrial Conduction 


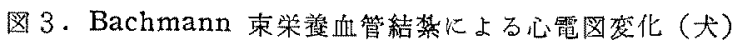
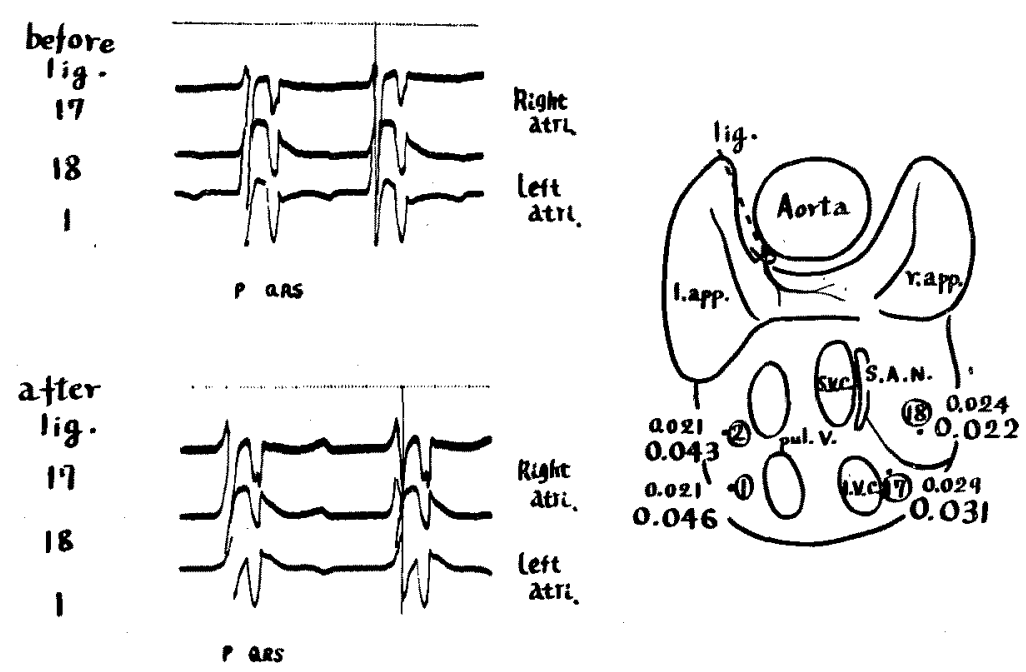

種心筋の存在等を証明して来た。

そこで先に述へた様な在来報告された症例を説 明する為に洞結節からの3系路を模型的に表し， 且つその色々な部分の障害によつておこるである う心電図の変化を模型的に示して（図1）以上の 如き症例の解明に役立つ加否加を考察してみた。

1）洞・左房刺激伝導障害 症例 1 .

図 2 江標淮肢第 II 誘導, $\mathrm{CR}_{1}$ 及び食道誘導の同 時描写である. 第II 誘導では著明ではないが $\mathrm{CR}_{1}$ に於いてP波が著明に分裂し完全に二つの山とし て諗められ全P波の持続時間は0.16秒に及んでい る.こ〉で正常者心電図でも識られる如く前の山 が右心房への刺激伝播であり，後の山は同時描写 の食道誘導P波と一致していることよりみても左 房への刺激伝播であることがわかる。即ち本症 例は洞左房伝咅障害の症例で模型図 $\mathrm{b}$ に相当する ものと思われる。このことは次の事害より証明せ られる.即方教室の大沢7は組織学的に洞結節頭 部より出て大動脈基部後方を右房より左房に謷ぐ Bachmann 束中に特種心筋束を証明した。 そし てこの部を栄養する冠動脈心房枝を結禁すると同 様の状態が犬により実験的に証明出来た（図了）. 及この様な左房表面で誘導したP波の遐延は直接 Bachmann 束を選択的に結紮しても同棣の結果

が得られる8)からである。

2) 左右房間ブロック

症例 2 .

京大前川内科の緒方の症例6) は全般としては心 房粗細動であり乍ら， $\mathrm{CR}_{2}$ で別に整調の洞調律 $\mathrm{P}$ 波を認める心電図が得られている。

症例 3.

図 4 はV $V_{2}$ で心房粗動波を認めるのに食道諉導 では粗動であれば当然認められる筈のF波がどの 深さに於いても認めることが出来なかつた例であ， る.これは食道内の電極が左心房から距つていた とも考えられないとはないが，むしろ左心房が 細動状熊を呈していたことも考えられる。

以上の 2 症例は左右の房が別々の調律となつて いる場合, 即亏左右房間ブロックと考えられ，図 1 の模型図Cに相当するもので洞結節から左房へ 行く筋束の他に左房上り田原結節に行く筋束をも 障害されたものと思われる。

Bachmann 束の他にこの筋束为存在すると思 われる冠静脈洞開口部附近をも結督すると実験的 にこれが模做することが出来るからである．四 5 は左右同調律であつた犬のアコニチン粗動が上述 の 2 力所の結禁により左右別々の調律に遮断され たものである9.

3）洞・田原系刺激伀学障害 
図 4. 左右房間ブロックの症例
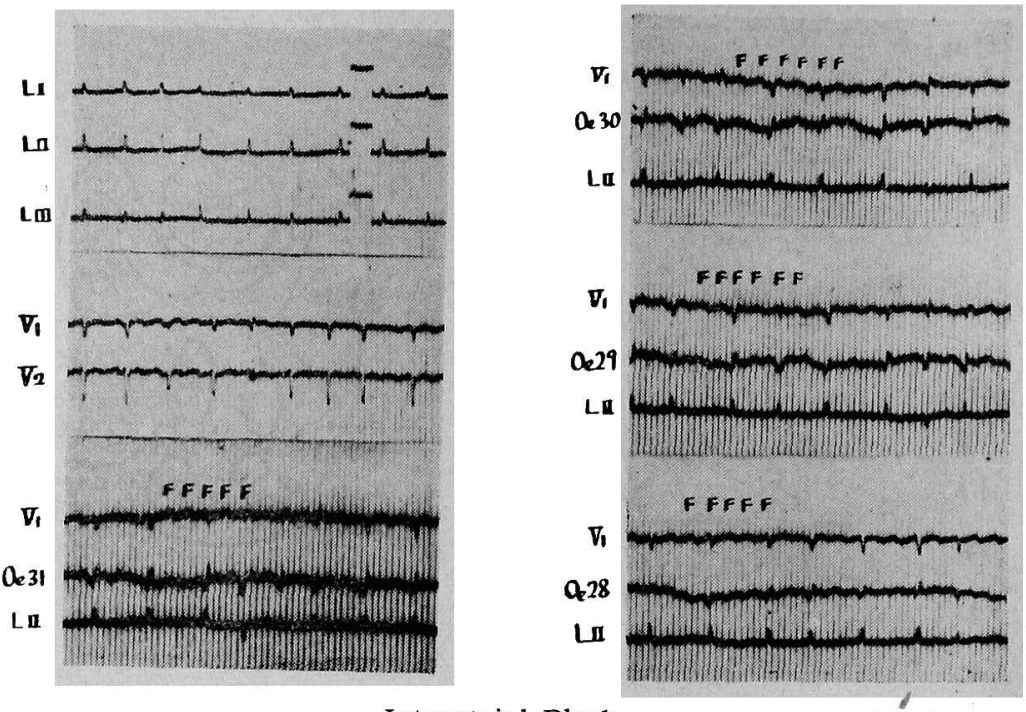

Interatrial Block

図 5. 左右房間ブロックの実験例（犬）

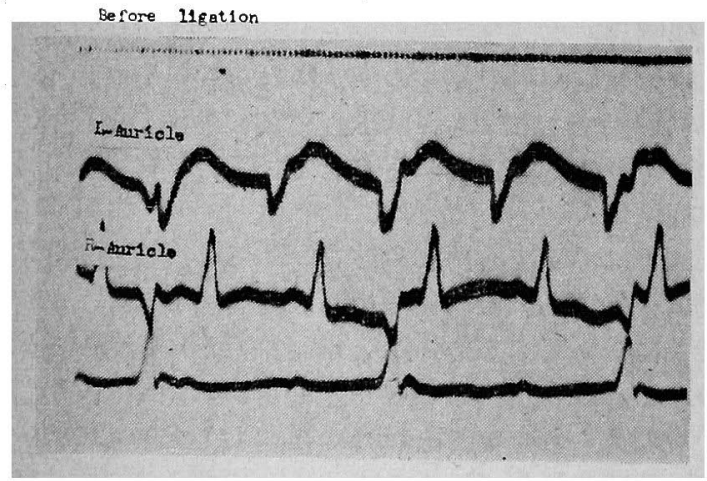

Immediately after B \& $S$ Hgations

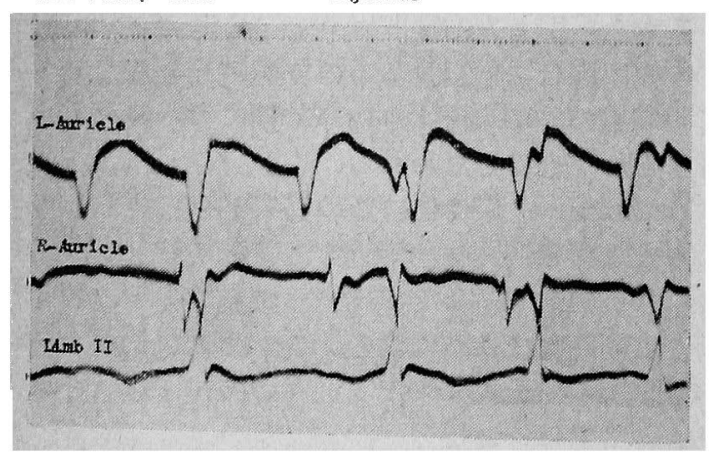

図 6. 洞・田原間特種心筇系

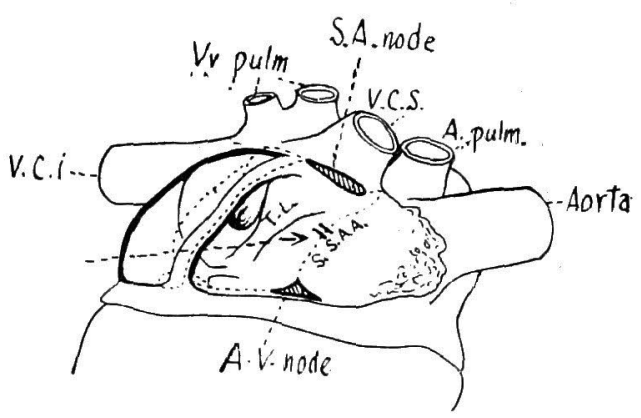

P Q 延長の心電図は一般に房室ブロック第 I 度 と理解されているが図 1 の模型図 d の如く洞・田 原系の障害によつてもおこるわけである。大沢10) は組織学的に洞・田原間に 3〜4の特種心筋系路 を認め(図 6), 立石11)はその選択的遮断によつて PQ延長を認めた。文図 7 は細胞内微小電極法 を用いてこの経路の内前方のもの即ち Systema septo-angularis anterior 切断した際田原結 節の興倡氒遅延し且つこの興奮の立上りがおくれ Step を形成するのを認めたものである. 㕛洞結 節・田原結節間の系路を全部切断する之心房の上 部は洞調律に下部は結節調律に変化するのを同じ く細胞内電極で認めることが出来た。 
図 7, 洞・田原間特喠心筋系切断実験（犬）

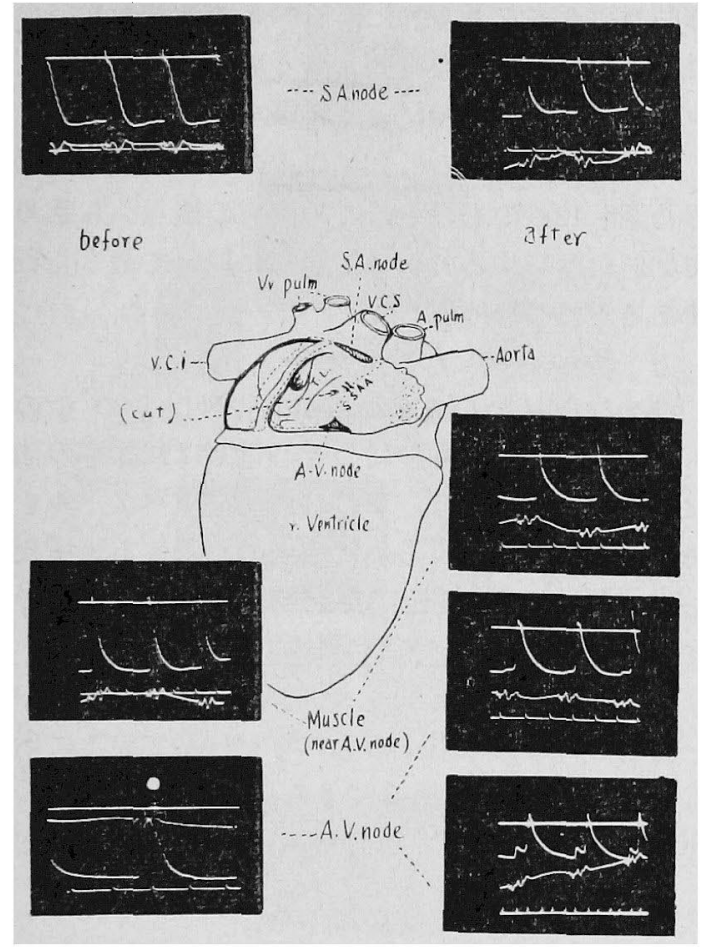

上の曲線： 微小電極による細胞内電位曲線 (上段 : 洞 結節 中段：田原結節附近 下段：田原結節）

下の曲線：上の曲線と同時に洞結節部表面より誘導 した単尿誘導心電図

4）洞・右房刺激伝導障害, その他

$\mathrm{P}$ 波の著明な変形は結節よりの逆伝導のみなら ず模型図 e の如き洞・右房系の刺激伝導障害の可 能性も考虑されなければならない，逆に $\mathrm{P} Q$ 短縮 例も結節調律或は房室結節の生理的伝導抑制の欠 除を想定するだけでなく, 模型図 $\mathrm{f}$ の如き洞・田 原等のみ健在で左右房への伝播に障害がある場合 も考えられる。

症例 4 .

$P Q$ 短縮例であるが $\mathrm{P}$ の形は正常で食道内誘導 心電図を分析すると左心房では刺激が正常洞調律 の場合と同様上方から下方に向つて進んでいるの が認められた。

以上の如き特種な心房波を示す症例を分析して 確かめる為には標準肢誘導と右房を比較的よく反
映する $V_{1}$ 或は $V_{2}$ 及び左房を表現する食道誘導 とを同時描写して検討することが望ましい，又房 間ブロックの症例が甚だ稀であるのは，先にも述 べた如く洞結節より左房への伝導路の障害のみで は左房への刺激伝達が遅延するのみであり, 同時 に冠静脈洞開口部附近の左房から田原結節に連な る特種心筋をも障害されて初めて左右房間の遮断 がおこるのであるためと思われる。

小括

1）心房に於汗る刺激伝導障害を特種心筋系路 があるものとして分類し，それらの症例を示して その根拠について述べた。

2）これらの症例の分析には標準肢誘導を $V_{1}$ 或は $\mathrm{V}_{2}$ 及び食道誘導と共に同時描写するとよい と思われる。

3）房間ブロックの症例が甚だ稀なのは刺激伝 導路の通る特定の 2 力所が選択的に障害されなけ ればおこらないからであると思われる。

第 2 章 心室内刺激伝導障害

完全脚ブロックはQR S の幅が0.12秒以上ある ことを以つて規定されるのが一般である.1930年 頃迄は四肢誘導でQR S の幅の延長の他に異常に 振幅の大きいこと，QR Sに著明な結節形成のあ ること，及び逆行性T波を伴なうことも規準とし て挙げられ，そのブロック側の診断については Lewisの犬に於ける実験を根拠として普通型は左 脚ブロック，稀有型は右脚ブロックと考えられて いた。ところが1930年 Barker 等12は人屋や猿 を用いて実験してブロック側の解釈が逆であるこ とを提唱, Lewis の実験は犬を背位にすると心蔵 の位置が変動する為に逆の結果が得られたものと した.1932年 Wilson ${ }^{13)}$ は氏の単極誘導の理論 より人の胸壁誘導心電図を分析して, 以上のブロ ック規準の他にQR Sの形も大きさも略々正常で 後部 Sの時間が延びたものを, 右脚ブロックとし て追加した。これが右脚ブロックの殆どを占め, Wilson ブロックと呼ばれていることは周知の如 くである，そして単極誘導の理論が確立すると共 に現在では側の診断は胸壁誘導心電図QR S の形 
及び内效果波迄の時間より決定されるのが一般で ある。

ところが近年に至り胸壁誘導は心臓からの距り が可成りあるので真の䍩極誘導でなく，䓕つて activation time を测定するの山無意味であると

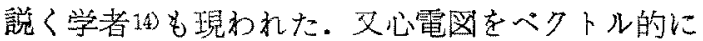

図 8.大電極を用いたん゙タトル心篦図の直交誘導法
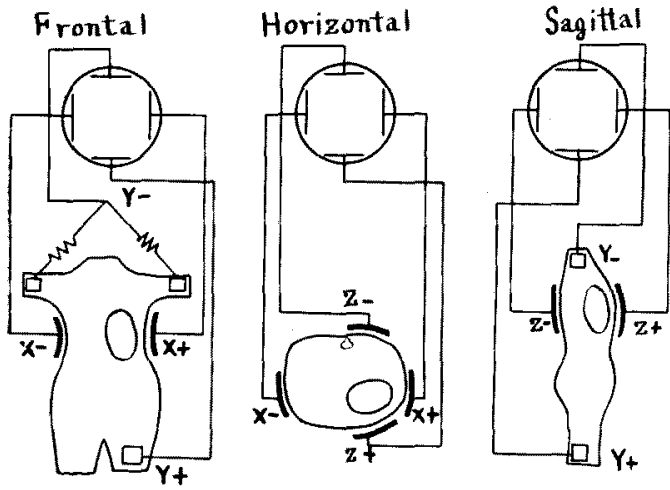

Schema of Orthogonal VCG
解䣋する傾向が一般に強くなつて胸壁誘導及び単 極肢誘導もべクトル的にみるべきであるともいわ れる。又ベクトル心電図も漸く盛となり殊に脚ブ ロックに関しては特によく特徴を現わすという。

そこでQR S群の0.12秒以上のもの，及び 0.10 秒乃至0.12秒のものを，この両方の観点办ら娟め て如何に解䐆するのが日常臨床に於いて最も有利 であるかにつき検討した。

方 法

標準肢誘導のQR Sの幅が0.12秒以上のもの 0.10 秒 0.12 秒の\&のにつ心電図は12誘導の他 に食道誘導を描写し，VCGは心発電べクトルを できるだけ忠実にみる為に演者の主張する大電極 を用いた orthogonal lead15)を採用して図8の 如く前額面，水平面及び矢状面を撮影した。

結果及び考察

QRSの0.12秒以上のものを一括して表 1 亿示 した。左から標淮肢誘導による Lepeschkin ${ }^{16)} の$ Subtype, QRS 時間, 胸壁誘導及び食道誘導の各

表 1. Complete RBBB

\begin{tabular}{|c|c|c|c|c|c|c|c|c|c|c|c|c|c|c|}
\hline & Disease & Subtype & QRS & $V_{1}$ & $V_{2}$ & $V_{3}$ & $V_{4}$ & $V_{s}$ & $V_{6}$ & Je & & AI & $\bar{R}$ & $H$ \\
\hline 155 & He patitis & III & 0.125 & 0,008 & 0.020 & 0.043 & 0.043 & 0.043 & 0.043 & & + & - & 3 & - \\
\hline 165 & Cong H.D & Ior II & 0.125 & $0.070^{7}$ & $0.085^{8}$ & 0.050 & 0.058 & $0.020 \mid$ & 0.025 & & + & - & 7 & + \\
\hline 02 & & sus & 0.125 & $0.100^{2}$ & $0.100^{R^{2}}$ & & 0.037 & 0.037 & 0037 & & + & + & 3 & 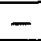 \\
\hline 265 & no & $\underline{u}$ & 0.125 & $0.104^{8}$ & $0.091^{\mathrm{P}}$ & 0.062 & 0.025 & 0.025 & 0.041 & & + & + & 3 & - \\
\hline 266 & no & II & 0.125 & $0.104^{\mathrm{R}}$ & $0.093^{k}$ & 0.652 & 0.025 & 0020 & 0033 & & + & - & 3 & - \\
\hline 350 & Hypertensio & III & 0.160 & $0.096^{8}$ & 0.096 & 0.042 & 0042 & 0.037 & 0.042 & & + & + & 3 & - \\
\hline 325 & no & II & 0120 & 0.041 & 0040 & 0020 & 0020 & 0.025 & 0025 & & + & -1 & 3 & $=$ \\
\hline 353 & Aortic insuth & III & 0.125 & 0.117 & 0.054 & 0.058 & 0066 & 0.066 & 0066 & & + & \pm & 3 & - \\
\hline 364. & Hypertension & II & 0.130 & $0.100^{\mathrm{k}}$ & 0.100 & 0040 & 0060 & 0.060 & & & + & + & 3 & 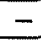 \\
\hline 370 & & III & 0.130 & $0.100^{8}$ & 0.070 & 0.030 & 0.040 & 0.030 & 0.030 & 0.035 & + & + & 3 & - \\
\hline 393 & & III & 0.120 & 0.080 & $0.075^{\mathrm{R}}$ & 0.030 & 0.030 & 0.025 & 0.030 & & + & + & 9 & - \\
\hline 386 & $\begin{array}{l}\text { Puc. toc } \\
\text { Hypertension }\end{array}$ & III & 0.120 & 0.100 & $0.060^{R}$ & $0.05 \mathbf{R}^{\alpha^{2}}$ & 0.025 & 020 & 0.020 & & + & + & $\tau$ & - \\
\hline 402 & no & II & 0.120 & $0.090^{\mathrm{R}}$ & $0.100^{R}$ & $0.080^{k}$ & 0.040 & 0.040 & 0.040 & & + & + & 5 & - \\
\hline 406 & ertensient & II & 0.132 & $0.100^{R^{\prime}}$ & $080^{8}$ & $0.08^{\mathrm{R}}$ & 0.030 & 0.040 & 0.040 & & \pm & + & 5 & - \\
\hline 410 & no & II & 0.120 & $0.100^{\circ}$ & 0.040 & 0.040 & 0.040 & 0.040 & 0.040 & & $\div$ & + & 81 & $=$ \\
\hline 412 & thy & II & 0.120 & $0.100^{\circ}$ & $0.08^{k 2}$ & 0.080 & 0.040 & 0.040 & 0.040 & & + & + & 5 & - \\
\hline 413 & $\begin{array}{l}\text { Hyperten } \\
\text { Infarch }\end{array}$ & II & 0.125 & 0.100 & 0.090 & & 0.060 & 0.060 & 0.050 & & + & + & 8 & + \\
\hline 448 & no & II & 0.140 & 0.102 & $110^{R^{\prime}}$ & 0.100 & 0.090 & 0.040 & 0.044 & & & 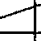 & & - \\
\hline 378 & no & If & 0.120 & 0.025 & 0.025 & 0.030 & 0,040 & 0.040 & 0.040 & & \pm & - & 7 & - \\
\hline 52 & Syphilis & III & 0.125 & 10 & 085 & 0.063 & 0.042 & 0.042 & 0.042 & & + & + & 2 & + \\
\hline
\end{tabular}

T.S. ..... Terminal Slowing.

R. .... Rotation of Horizonlal VCG

T.A. '.... Terminal Appendage

H. … Right Vent. Hypertrophy 
図 9. 右脚ブロックの症例

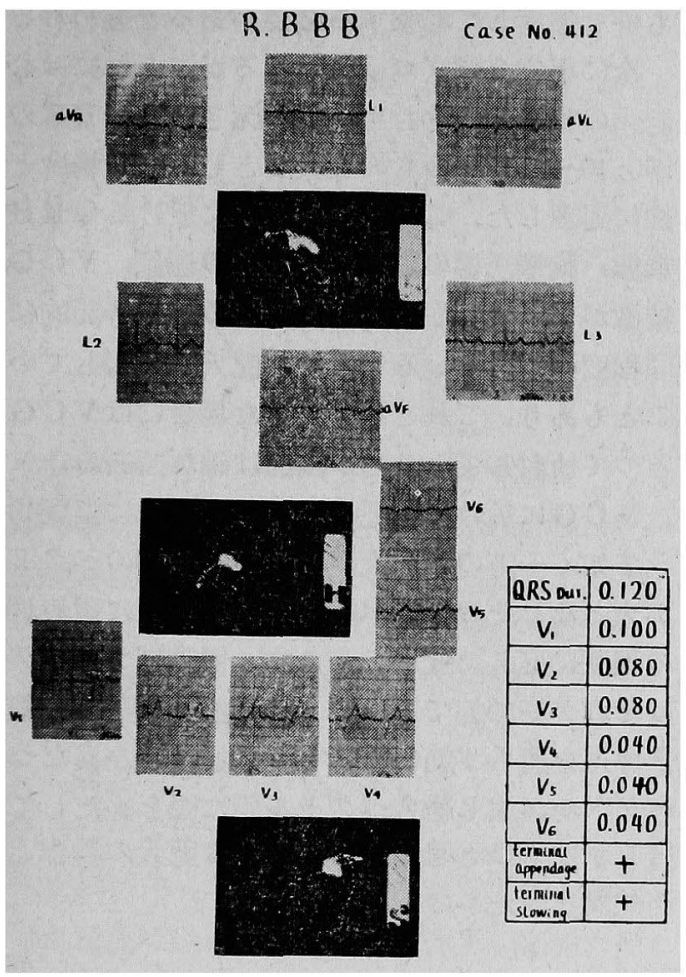

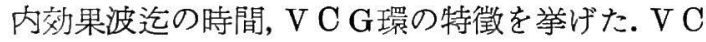
G環の特徵としては右脚ブロックでは図 9 の如く 主環は正常に比し前後に扁平になり終末部は右前 方及は右万に副時点が密集して突出し, terminal appendage を形成するか，少なくも右後方よ り緩徐に原点に戾り刻時点の集合が認められる。 左脚ブロックでは図10の如くベクトル環は左後上 方に向かい中間部に刻時点の密集が認められ, 又 回転方向が水平面ベクトルに於いて正常と逆に時 計方向であることが特徵である.

表をみると完全ブロックでは四肢誘導の型, 胸 壁誘導の activation time, 胸壁誘導をべクトル 的にみた場合, V C Gの特徵，いずれからみても大 多数の症例でその判定が一致する. 即ち完全ブロ ックに於いては標準肢誘導のみでも可成り充分に 判定出来るわけである. 併しこれのみでは Lepe-

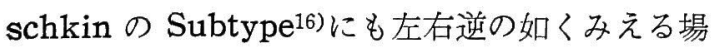
合が挙げられている様にこの樣な症例には是非
図10. 左脚ブロックの症例

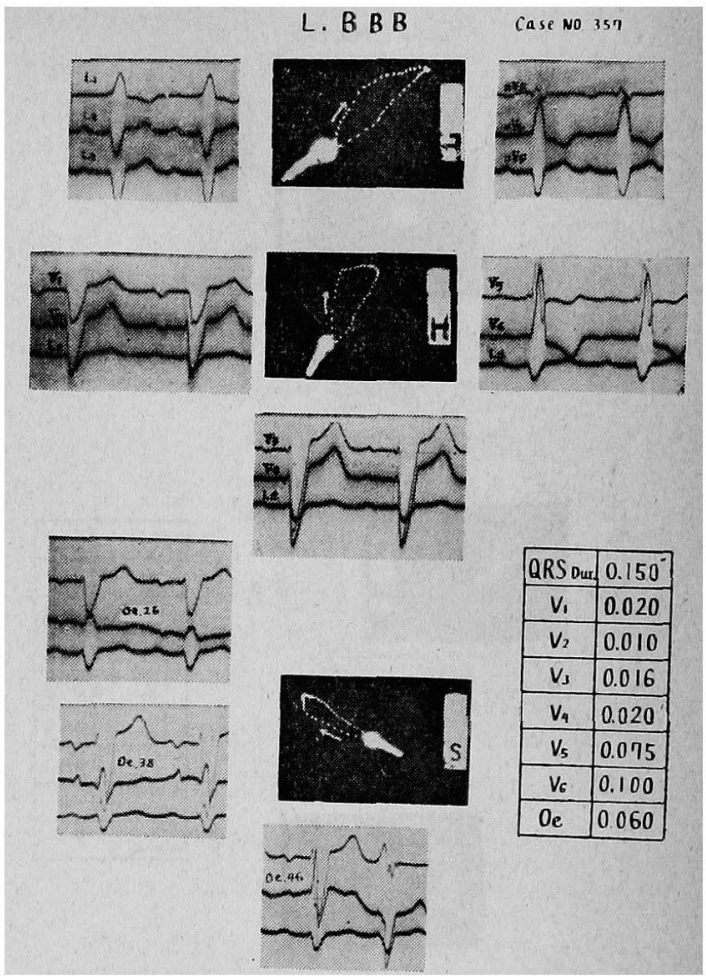

共胸壁誘導等が必要である. 又表中症例325及び症 例 364は $V_{1}$ 及び $V_{2}$ で到達時間が遅延している のみならず食道誘導に於いても遅延がみられる。 即ちこれらの例では右室のみならず左室後壁基部 に於いても遲延が存在することがこれにより識ら れたわけである。従つて以上のことから判断すれ ば，胸壁誘導のみならず左心室後壁基部に接する 食道誘導をも含めてその各々の activation time を測定することが数字的に必ずしも正確と言い得 ない迄も心室各部分に刺激の到達する時間を略々 識り得るので日常臨床に於いて甚だ有利であると 思われる。

垪し症例 155は図11に示す如くQRSは 0.125 秒あり完全脚ブロックと思われるが $\mathrm{V}_{1}$ 或は $\mathrm{V}_{2}$ に late $\mathrm{R}$ を認めず又刺激到達時閒をみても著明 な遅延を認めない.僧しV C Gでは定型的な terminal appendage はないが右後方より原点に 戾りこの部に剖時点の密集が認められ右脚ブロッ クと診断される。即ちこの様な特種な場合は単に 


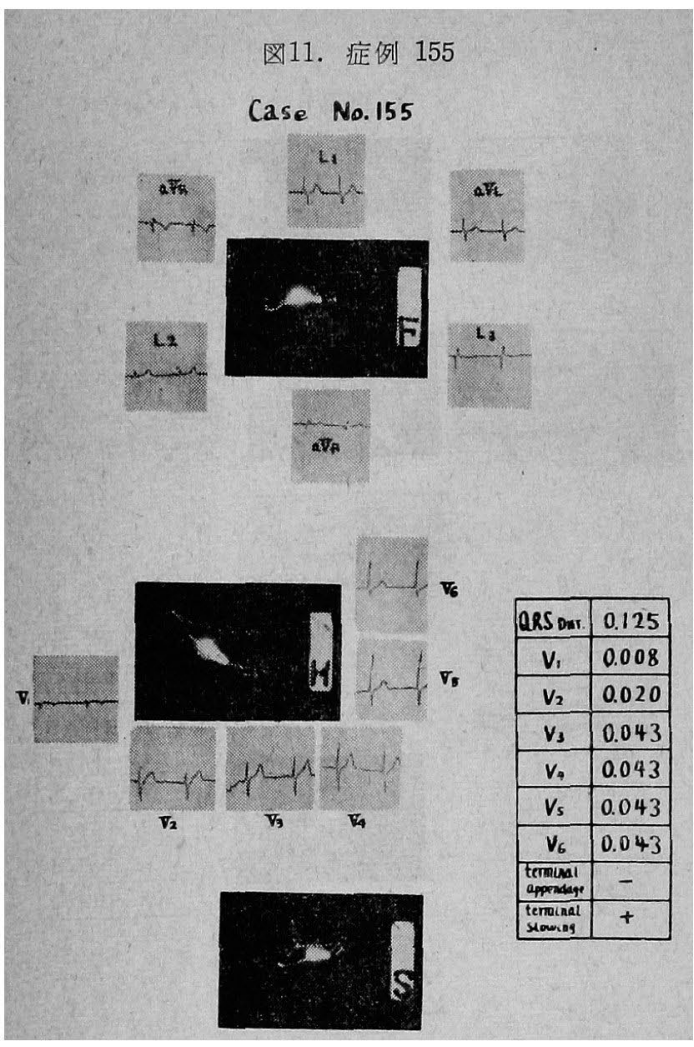

ベクトル的に眺めるだけでなく，やはりVCGを も併せ描写して考察する必要があると思われる。

次に不完全脚ブロックであるが，これには心室 肥大の場合等を含む可能性が大きい，QR S の幅 が0.10〜0.12秒のものを表 2 として先の場合と同 様に処理した。この場合も $\mathrm{V}_{1}$ に於ける Q R S 形態, 胸壁誘導の刺激到達時間の遅延, $\mathrm{V} \mathrm{C} \mathrm{Gの}$ 特徵が一致する症例も可成りあるが，時間的には 同程度延長している場合で旮肥大に起因している こともあり,これと判断困難な場合にはV C Gを とつて検討してみる方が鑑別は確かである.

V C Gに於ける室肥大の特徴は図12に模型的に 示す如く一方の室肥大があればその側のベクトル が大となりその影響が総合べクトル環に現われそ の程度に応じた変形を来たす．他方脚ブロックで はそれが局部的であつてもその部分は正常の刺激 伝導系を通らず筋伝導をもつて拡がる為異なつた ベクトルが生じ総合べクトル環に歪を来たして異 常を示すものと思われ，その形は肥大の場合とは 当然異なつたものとなる。

表 $2.0 .100 \leqq \mathrm{QRS}<0.120$

\begin{tabular}{|c|c|c|c|c|c|c|c|c|c|c|c|c|c|c|}
\hline & Diseases & Subtype & HQRS & $V_{1}$ & $V_{2}$ & $V_{3}$ & $V_{4}$ & $V_{5}$ & $V_{6}$ & & \begin{tabular}{|l|}
$v$ \\
$T$
\end{tabular} & CG & & \\
\hline 276 & A.S.D. & $\nabla$ & 0.101 & $0.093^{k}$ & $0.09^{R^{2}}$ & 0.041 & 0.033 & 0.041 & 0.041 & & + & - & 21 & $\mathrm{I}+\mathrm{H}$ \\
\hline 355 & Cong. H. D. & II & 0.100 & 0.075 & $0.08^{\mathrm{R}}$ & 0.033 & 0.033 & 0.033 & 0.033 & & + & - & 3 & I \\
\hline 308 & no & II & 0.100 & 0.020 & 0.020 & 0.025 & 0.025 & 0.025 & 0.033 & & + & - & 3 & \\
\hline 360 & no & II & 0.100 & $|0.083|$ & 0.041 & 0.032 & 0.049 & 0.041 & 0.037 & & $1+$ & + & 15 & I \\
\hline 371 & Cong. H.D. & II & 0.110 & 0.065 & 0.040 & 0.030 & 0.030 & 0.030 & 0.040 & & + & + & 5 & I \\
\hline 403 & Hypertension & II & 0.100 & $0.080^{\pi}$ & 0.080 & 0.020 & 0.030 & 0.030 & 0.030 & & + & - & 5 & I \\
\hline 404 & Hypentersion & II & 0.104 & $0.080^{R}$ & $0.080^{R^{\prime}}$ & $\begin{array}{l}0.080^{R} \\
\end{array}$ & 0.035 & 0.040 & 0.040 & & - & - & 5 & $I$ \\
\hline 411 & no & II & 0.100 & 0.040 & 0.025 & 0.030 & 0.030 & 0.030 & 0.030 & & - & - & 85 & $\mathrm{H}$ ? \\
\hline 407 & no & N & 0.100 & 0.030 & 0.040 & 0.040 & 0.040 & 0.040 & 0.040 & 0.040 & \pm & - & 5 & \\
\hline 409 & Hypertension & II & 0.100 & $0.06^{r \prime}$ & 0.020 & 0.020 & 0.040 & 0.045 & 0.050 & & + & - & 85 & \\
\hline 247 & M.S+P.D.A. & II & 0.104 & 0.060 & 0.072 & 0.062 & 0.041 & 0.041 & 0.041 & & - & - & 2 & $H$ \\
\hline 372 & no & III & 0.100 & 0.090 & $0.090^{R^{\prime}}$ & 0.030 & 0.050 & 0.040 & 0.020 & & - & - & 5 & \\
\hline 416 & no & II & 0.108 & $0.088^{k}$ & $0.09^{\mathrm{R}^{\prime}}$ & 0.032 & 0.041 & 0.041 & 0.041 & & & 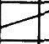 & & $I$ \\
\hline 434 & no & II & 0.100 & 0.085 & 0.080 & 0.060 & 0.045 & 0.045 & 0.041 & 50 & 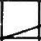 & $=$ & & $I$ \\
\hline 418 & Pul. Tbc. & & 0.100 & 0.037 & 0.029 & 0.041 & 0.037 & 0.038 & 0.038 & 50 & - & - & 5 & \\
\hline 408 & no & II & 0.108 & 0.030 & 0.020 & 0.040 & 0.030 & 0.030 & 0.030 & & \pm & - & 5 & \\
\hline 198 & Cong. H.D. & & 0.100 & 0.041 & 0.041 & 0.041 & 0.050 & 0.041 & 0.031 & & - & - & 2 & $\mathrm{H}$ \\
\hline 329 & M.S. & & 0.100 & 0.062 & 0.050 & 0.047 & 0.031 & 0.031 & 0.041 & & & $=$ & & $\mathrm{H}$ \\
\hline 207 & Fallot & & 0.100 & 0.075 & 0.042 & 0.042 & 0.033 & 0.042 & 0.033 & & - & - & 2 & $\mathrm{H}$ \\
\hline \multicolumn{7}{|c|}{ 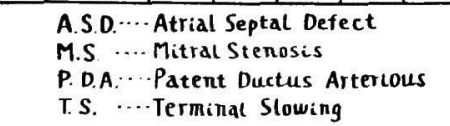 } & \multicolumn{8}{|c|}{$\begin{array}{l}\text { T.A..... Terminal Appendage } \\
\text { R. … Rotation of Horizontal VCG } \\
\text { I. … Incomplete Right B B B } \\
\text { H. …. Right Vent. Hypertrophy }\end{array}$} \\
\hline
\end{tabular}


図12. 室肥大に上る水平へっっル環の变形

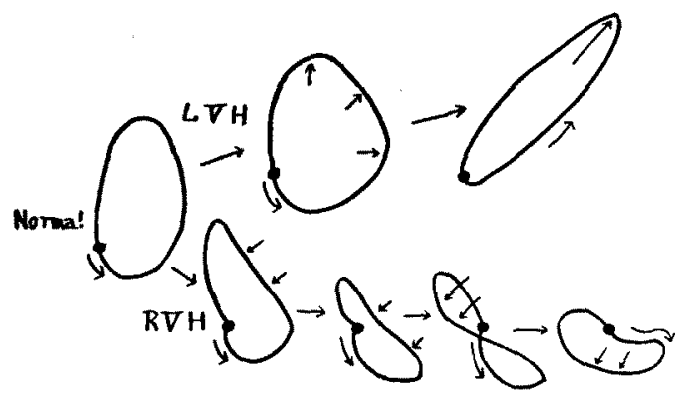

Horizontal VCG in Vent. Hypertrophy

症例 407はQR Sが0.10秒であるが胸部誘導の 刺激到達時間はいずれも略々正常でありV C Gを みるとそのベクトル環は異常を示し不完全脚ブロ ックと考えられる。胸壁誘薄は心圶の総ての部分 の到達時間を識り得るわけではないからそれ以外 の部分に遅延があるものと思われる。

\section{予後及びその他}

说来左脚プロックは比較的稀で且つ予後も右却 ブロックに比し不良といわれるが演者の扱つた症 例でも左脚ブロックは少なく（表 3）, 且つ予後名 不良のものが多かつた。2例は長年の経過を識る ことが出来たが左脚ブロックになる以前に長年左 室肥大の像を呈し，QRSはその睢の形で漸次延 長して遂に典型的の左脚ブロックを形成している
のがみられた（図13）。そしていずれも左脚ブロッ ク完成後約 1 力年で死亡している. 即ち左脚ブロ ックは広範囲に高度の変化を来たして初めて来る ものが多いので予後も不良となり, 又一旦脚ブロ ックを呈する程になると是晚死亡すること多い ので例数も台少ないこと〉なるのであろう。

之に反して右脚ブロックは展々健康者にも見ら れるというが，演者も某工場の從業者 658名を心 電図稌診した中に 4 例（ $0.6 \%)$ に完全右脚ブロ ックを，8例（1.2\%）に不完全右脚ブロックを 認めたが，左脚ブロックは 1 例も認めなかつた。

小括

1) 脚ブロックの診断は胸壁誘獎及び食道誘導 の内效果波迄の時間を测定し, そのQRSの形を 参考として判断するのが最もわかり易く数字は必 すしも全く正確であるとはいえない迄も日常臨床 に於いては便利である。併し稀には特種なものが あつてV C Gに頼らねばならぬ場合がある。

2）右不完全脚ブロックと右心室肥大とはまぎ らわしい場合があり，その区别にはVCGの方が 判断し易い. $V_{1} の$ late Rだけで判断すると誤 りを犯すことがある。

3）食道誘導は左室後壁基部の刺激到達痋延の 有無を識る為には是非些必要である。

4）左脚プロックは比較的稀であるが，おこれ

表 3. LVH \& LBBB

\begin{tabular}{|c|c|c|c|c|c|c|c|c|c|c|c|}
\hline & Disease & QRS & $V_{1}$ & $V_{2}$ & $\nabla_{3}$ & $\nabla_{4}$ & Vs & $V_{6}$ & Oe. & icG & \\
\hline 420 & Hyperitursing & 0.125 & 0.015 & 0.020 & 0.013 & 0.000 & 0.100 & 0.100 & 0075 & & $\angle B B B$ \\
\hline 416 & $H_{\text {pertencion }}$ & 0.100 & 0.025 & 0.025 & 0.058 & 0,058 & 050 & 0.050 & 75 & & $V H$ \\
\hline 446 & Selerosis & 0.140 & 0.020 & 0.020 & 0.015 & 0.025 & 0.100 & 0.100 & 100 & & $\angle B B B$ \\
\hline 357 & Aorlieinsulf & 0.150 & 0.020 & 0.010 & 0.016 & 0.020 & 0.075 & 0.100 & & & $\angle B B B$ \\
\hline 320 & Hyperlension: & 0.125 & 0.021 & 0.038 & 0.032 & 0.052 & 0.042 & 0.042 & & & $L V H$ \\
\hline 259 & Hypatension & 0.104 & 0.027 & 0.021 & 0.031 & 0.042 & 942 & 0.031 & & & LVH \\
\hline 194 & Hpportousion & 0.100 & 021 & 0.038 & 031 & 0.063 & 352 & 042 & & & LVH \\
\hline 438 & Syphilis & 0.140 & 0.020 & 0.013 & 0.013 & 0.020 & 0.115 & 0.100 & 0 & & $\angle B B B$ \\
\hline 433 & Selerosis & 0.145 & 0.017 & 0.020 & 0.013 & 0.050 & 0.087 & 0.075 & 0.075 & & $\angle B B B$ \\
\hline 418 & Hipportension & 0.100 & 0.013 & 0.020 & 0.040 & 0.040 & 0.040 & 0.045 & & & $L V H$ \\
\hline
\end{tabular}


図13. 左室肥大より左脚ブロックへの移行例

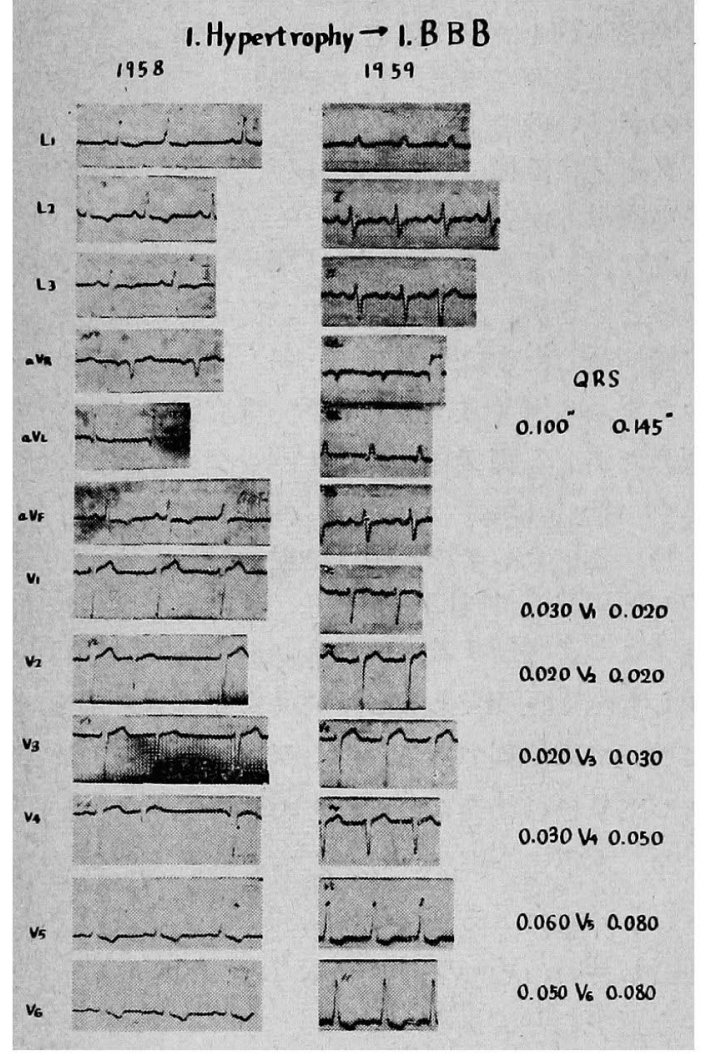

ばその予後は重篤のことが多い。これに反し右脚 ブロックは健常者にも認められ病的意義に関して の判断は慎重でなければならない。

\section{結語}

以上刺激伝導障害の内，心房内及び心室内に於 ける障害について前者では演者が長年月主張して 来た特種心筋采の存在を肯定して症例とその理由 を解説し，後者に於いては如何なる観点に立つて 脚ブロックの局所の䛦断を下すのが日常臨床に有
利であるかについて考察した。

講演を終るにあたり光栄ある機会を与兄られた堂野 前会頭, 小宮前会頭, 日本循環器学会原会長, 木本前会 長に感謝する. 又多大の御指導御鞭撻を戴いた前川教授 に深甚なる謝意を表すると共に, 症例との他御援助を戴 いた前川内科粕方, 野原両博士, 三重県立大学小坂, 高 崎両教授, 松阪市民病院野田博士, 羽津病院山口博士に 感謝する. 又日夜労苦を惜しまなかつた共同研究者一同 に敬意を表する。

\section{共同研究者}

佐野 猶則, 立石 義雄, 加藤 昭, 矢野昭 玉垣 有信, 生田 清三, 井上 義信, 山崎 茂郎 今谷 和郎, 伊藤摩訶雄, 森島 利仁, 玉井甫 金津 郁哉, 服部一男, 加藤 涌三,

東芝冨土工場診療所 寺岡鎮婎

\section{文献}

1) Condrelli, L.: Z. f. d. ges. exper. Med., 68: 493, 516, 1929. - 2) Schrumpf, P.: Arch. de mal de Coeur, 13 : 168, 1921. - 3) Laufer, S.: Zeitschr. f. Klin. Med. $127: 678,1935 .-4$ ) Decherd, G.M. et al.: Am. Heart J., 31 : 352, 1946。一- 5) 前川孫二郎, 高安正夫：日本循環器病 学, $2: 137,1936 .-6)$ 緒方豊, 汐見交隆: 日本 循環器学誌, $14: 132,1950$. - 7) 大沢正義 : 同上 $23: 62,1959 .-8)$ Takayasu, M. et al.: : 同上, $18: 414,1955$. - 9) Fujiwara, M.: Mie Med. J. $9: 177,1959 . \quad-10)$ 大沢正義：日本偱環器学 誌, $23: 1014,1959$. 一 11) 立石義雄：日本循環 器学誌, $23: 726,1959$. - 12) Barker, P.S. et al.: Am. Heart J., 5 : 702, 1930. - 13) Wilson, F.N. et al.: Am. Heart J., 7 : 305, 1931. 9: 459, 1934. - 14) Frank, E.: Electrophysiology of the Heart. New York Academy of Science, 1957, P 980. - 15) 高安正夫, 营原努他：日本内 科学会雑誌, $44: 77$, 1955. Mie Med. J., $8: 1$, 1958. -16) Lepeschkin, E.: Modern Electrocardiography. Vol.1, Williams \& Wilkins, Baltimore, 1951. 